\title{
Genetic Algorithm Model for Abrasive Water Jet Machining of Inconel 617
}

\author{
Anish Nair, Somasundaram Kumanan
}

\begin{abstract}
This article details the methodology for the development of a multi objective optimization model for the abrasive water jet machining of Inconel 617. Genetic algorithm is the tool used for the optimization process. Abrasive water jet drilling of Inconel 617 is conducted using the Taguchi design of experiments. The various input factors considered are water pressure, abrasive flow volume and standoff distance. The responses selected for this study are overcut, circularity and drill rate. A simultaneous multi optimization model is developed using genetic algorithm. The optimization is done with four stages where in different weightages are added to the input factors and the results have been reported.
\end{abstract}

Keywords : Abrasive water jet, Inconel 617, Genetic algorithm, Circularity.

\section{INTRODUCTION}

$\mathbf{N}_{\text {ickel based superalloys are continuously being used for }}$ the development of advanced boiler components and Inconel 617 is one of the most commonly used among them [1], hence it has drawn the attention of researchers. Conventional machining processes have their own limitations while processing superalloys hence unconventional machining needs exploration. Inconel 617 is a category D superalloy [2] and can be worked only with advanced nontraditional machining processes. Abrasive water jet machining (AWJM) has got its popularity primarily because there is no friction or excessive heat formation and the surfaces produced are not exposed to high temperature [3]. High speed abrasive particles in the form of a slurry carries out the high speed micro cutting operation [4].

AWJM studies have been conducted in various metals and Inconel 718 is one of the popular alloys which has been studied. Kerf dimensions and properties in the AWJM of Inconel 718 has been widely reported [4] [5]. From popular literature it is established that jet pressure is a significant factor affecting the process rate. Also, standoff distance is one of the factors which imparts the geometric features to the machined surface [6]. Abrasive Water Jet Drilling is achieved by having a zero feed rate and the jet pierces [7] through the material. Abrasive water jet drilling of exotic materials has seldom been studied but there are other common materials on which the studies have been conducted [8] [7]. AWJM is also

Revised Manuscript Received on December 5, 2019

* Correspondence Author

Anish Nair*, Mechanical Engineering, Kalasalingam Academy of Research and Education, Krishnankoil, Virudhnagar, India. Email: anishn@live.com

Kumanan Somasundaram, Production Engineering, National Institute of Technology Tiruchirappalli, Trichy, India. Email: kumanan@ nitt.edu good tool for the machining of glass and a work on it reported that polymer based abrasives produce better quality holes [9] [10].

Circularity, Overcut are some of the geometrical features which have been rarely studied in such non-conventional machining processes. Hence an attempt is made to incorporate these features in the study and use an advanced optimization technique to solve the same.

\section{EXPERIMENTATION}

OMAX 2626 is the make of the equipment used for the purpose of erosion based machining Center. The setup is arranged shown in Figure 1.

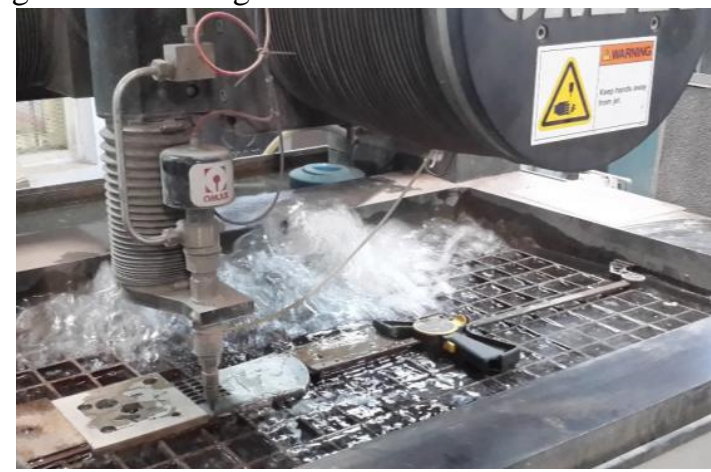

Fig. 1 Experimental setup of the AWJD process

Inconel 617 plate of size $150 \mathrm{~mm} X 75 \mathrm{~mm} X 10 \mathrm{~mm}$ is machined with abrasive Garnet of size 80 mesh which passes via a tungsten carbide nozzle.

Inapt combination of factors lead to partial jet penetration and in order to avoid this trial experiments were carried out. The Taguchi L9 set up is used for the experimentation which has a 3 parameter 3 level setting as in Table 1. The nozzle of diameter $0.76 \mathrm{~mm}$ produces the holes in the workpiece as depicted in Figure 2.

The drilling rate is the equivalent of erosion rate or the productivity and is calculated as follows,

Drilling rate $=$ Thickness of the workpiece $/$ Time taken to drill a through hole

And is computed with the record of time taken for the jet to make a through hole. Jet tends to lose its potential during the penetration which leads to varying top and bottom diameters Circularity of drilled holes is measured using the ARCS non-contact video measuring machine. Camera with high resolution focusses the hole and detects different points on the circle which are processed by it to develop a circular path. 
Table - I Experimentation set up

\begin{tabular}{|c|c|c|c|}
\hline S.No. & $\begin{array}{c}\text { WP } \\
(\mathrm{MPa} \\
)\end{array}$ & $\begin{array}{c}\text { SOD } \\
(\mathrm{mm})\end{array}$ & $\begin{array}{c}\text { AFR } \\
(\mathrm{kg} / \mathrm{min})\end{array}$ \\
\hline 1 & 250 & 1.5 & 0.24 \\
\hline 2 & 250 & 3.0 & 0.34 \\
\hline 3 & 250 & 4.5 & 0.44 \\
\hline 4 & 300 & 1.5 & 0.34 \\
\hline 5 & 300 & 3.0 & 0.44 \\
\hline 6 & 300 & 4.5 & 0.24 \\
\hline 7 & 350 & 1.5 & 0.44 \\
\hline 8 & 350 & 3.0 & 0.24 \\
\hline 9 & 350 & 4.5 & 0.34 \\
\hline
\end{tabular}

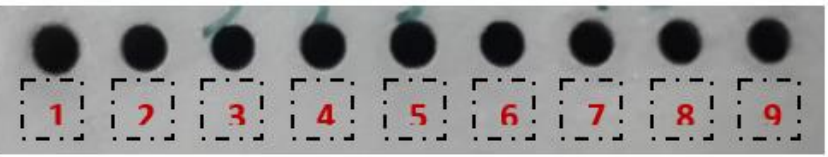

Fig. 2 Drilled holes in AWJD

Radial overcut is calculated from the equation shown below.

Top Over Cut $=\frac{\text { Top Hole Diameter }(\mathrm{mm})-\text { Nozzle Diameter }(\mathrm{mm})}{2}$

The different responses such as TOC - Overcut, CIRC Circularity and DR - Drill Rate measured after the experimentation are tabulated as shown below,

Table - II Responses measured in AWJD

\begin{tabular}{|c|c|c|}
\hline $\begin{array}{c}\text { TOC } \\
(\mathrm{mm})\end{array}$ & TC $(\mathrm{mm})$ & $\begin{array}{c}\text { DR } \\
(\mathrm{mm} / \mathrm{sec})\end{array}$ \\
\hline 0.385 & 0.0416 & 0.317 \\
\hline 0.429 & 0.0324 & 0.377 \\
\hline 0.434 & 0.0376 & 0.400 \\
\hline 0.394 & 0.0294 & 0.426 \\
\hline 0.425 & 0.0324 & 0.513 \\
\hline 0.401 & 0.0381 & 0.408 \\
\hline 0.400 & 0.0189 & 0.541 \\
\hline 0.383 & 0.0421 & 0.444 \\
\hline 0.409 & 0.0624 & 0.606 \\
\hline
\end{tabular}

\section{OPTIMIZATION USING GENETIC ALGORITHM (GA)}

Regression analysis is used for the development of objective function equations for the individual responses. A function is developed connecting the output responses to the corresponding independent variables. The equations are developed as shown below,

$$
\begin{gathered}
\text { TOC }=f(\mathrm{WP}, \mathrm{SOD}, \mathrm{AFV}) \\
\mathrm{CIRC}=f(\mathrm{WP}, \mathrm{SOD}, \mathrm{AFV}) \\
\mathrm{DR}=f(\mathrm{WP}, \mathrm{SOD}, \mathrm{AFV})
\end{gathered}
$$

As we are dealing with multiobjective optimization, a composite function of the form Objective $=$ TOC + CIRC $\mathrm{DR}$ is developed. Since genetic algorithm is a minimization tool the drill rate has been assigned as negative to make it a maximization factor. The individual regression equations for the respective factors are as shown below,

$$
\begin{aligned}
& \text { TOC }=0.293-0.000140 * \mathrm{x}(1)-0.0087 * \mathrm{x}(2)+0.894 * \\
& \mathrm{x}(3)+0.000128 * \mathrm{x}(1) * \mathrm{x}(2)-0.00159 * \mathrm{x}(1) * \mathrm{x}(3)-0.0733 \\
& * \mathrm{x}(2) * \mathrm{x}(3) ;
\end{aligned}
$$

$\mathrm{CIRC}=0.1913-0.000350 * \mathrm{x}(1)-0.04552 * \mathrm{x}(2)-0.349 *$ $\mathrm{x}(3)+0.000103 * \mathrm{x}(1) * \mathrm{x}(2)+0.000502 * \mathrm{x}(1) * \mathrm{x}(3)+$ $0.0609 * \mathrm{x}(2) * \mathrm{x}(3)$;

$\mathrm{DR}=0.357-0.000958 * \mathrm{x}(1)-0.1654 * \mathrm{x}(2)+0.603 * \mathrm{x}(3)$ $+0.000695 * \mathrm{x}(1) * \mathrm{x}(2)+0.00121 * \mathrm{x}(1) * \mathrm{x}(3)-0.0778 *$ $\mathrm{x}(2) * \mathrm{x}(3)$;

The lower and upper control bounds of the variables are,

Lower Bounds $=[250,1.5,0.24]$

Upper Bounds $=[350,4.5,0.44]$

\section{RESUltS AND DiscuSSION}

The genetic algorithm program is run from MATLAB software. In the first instance all the responses are given equal weightage and the equation is represented as follows.

Objective function $\mathrm{f}(\mathrm{x})=0.293-0.000140 * \mathrm{x}(1)-0.0087 *$ $\mathrm{x}(2)+0.894 * \mathrm{x}(3)+0.000128 * \mathrm{x}(1) * \mathrm{x}(2)-0.00159 * \mathrm{x}(1)$ $* \mathrm{x}(3)-0.0733 * \mathrm{x}(2) * \mathrm{x}(3)+0.1913-0.000350 * \mathrm{x}(1)$ $0.04552 * \mathrm{x}(2)-0.349 * \mathrm{x}(3)+0.000103 * \mathrm{x}(1) * \mathrm{x}(2)+$ $0.000502 * \mathrm{x}(1) * \mathrm{x}(3)+0.0609 * \mathrm{x}(2) * \mathrm{x}(3)-(0.357-$ $0.000958 * \mathrm{x}(1)-0.1654 * \mathrm{x}(2)+0.603 * \mathrm{x}(3)+0.000695 *$ $\mathrm{x}(1) * \mathrm{x}(2)+0.00121 * \mathrm{x}(1) * \mathrm{x}(3)-0.0778 * \mathrm{x}(2) * \mathrm{x}(3))$;

The fitness characteristics and the best values are shown in Figure and they are obtained as an outcome of the optimization problem. The iteration is continued till the fittest solution is obtained. The toolbox is set such that the iteration stops only when the algorithm returns similar minimal values.

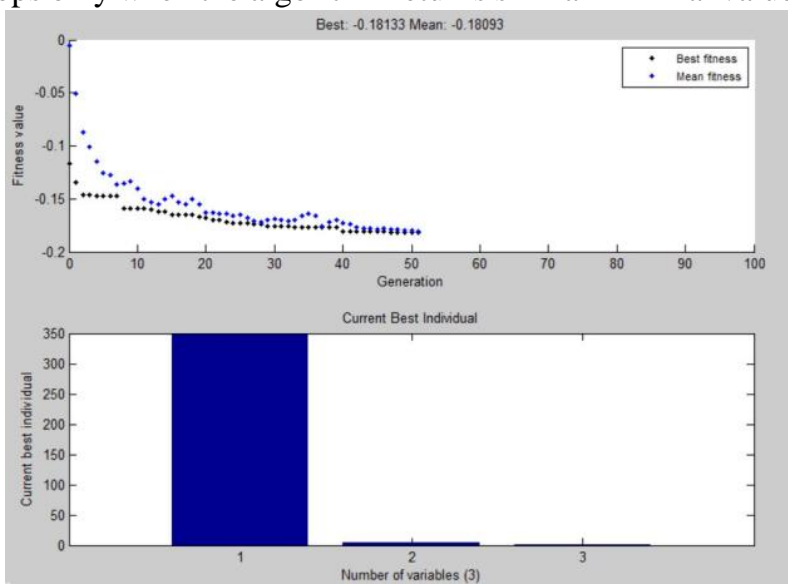

Fig. 3 Equal weightage for all the factors

Author The paper also deals with the analysis wherein the various output response are given different weightages and then the results are analysed. In order to add weights to any particular response that particular equation is multiplied by 10 as shown here, 


$$
\text { Objective }=\text { TOC } * 10+\mathrm{CIRC}-\mathrm{DR}
$$

Objective function (weightage for TOC) $=10 *$ $(0.293-0.000140 * \mathrm{x}(1)-0.0087 * \mathrm{x}(2)+0.894 * \mathrm{x}(3)+$ $0.000128 * \mathrm{x}(1) * \mathrm{x}(2)-0.00159 * \mathrm{x}(1) * \mathrm{x}(3)-0.0733 * \mathrm{x}(2)$ $* \mathrm{x}(3))+0.1913-0.000350 * \mathrm{x}(1)-0.04552 * \mathrm{x}(2)-0.349 *$ $\mathrm{x}(3)+0.000103 * \mathrm{x}(1) * \mathrm{x}(2)+0.000502 * \mathrm{x}(1) * \mathrm{x}(3)+$ $0.0609 * \mathrm{x}(2) * \mathrm{x}(3)-(0.357-0.000958 * \mathrm{x}(1)-0.1654 * \mathrm{x}(2)$ $+0.603 * \mathrm{x}(3)+0.000695 * \mathrm{x}(1) * \mathrm{x}(2)+0.00121 * \mathrm{x}(1) *$ $\mathrm{x}(3)-0.0778 * \mathrm{x}(2) * \mathrm{x}(3))$;

This function is further run in the genetic algorithm toolbox and the results have been detailed. The figure shows the rate of convergence to the optimal solution.

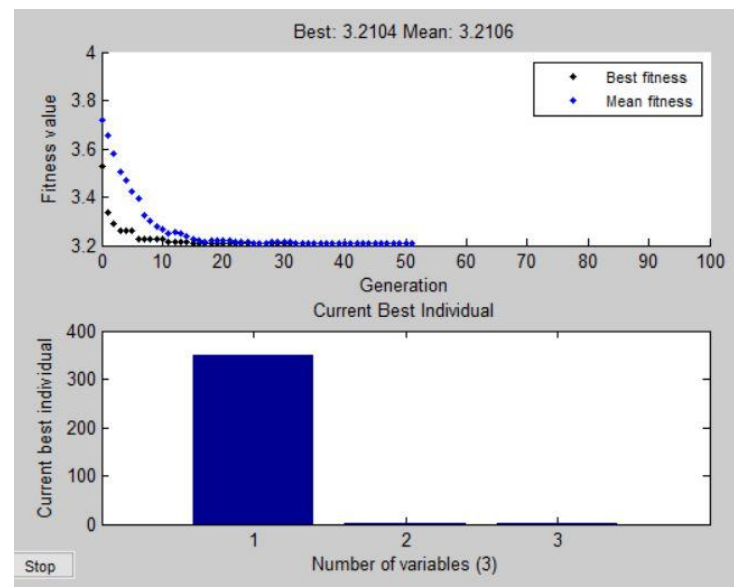

Fig. 4 Weightage for overcut

The weightage is given to circularity and the program is executed and the results are as shown in Figure.

Objective $=\mathrm{TOC}+\mathrm{CIRC} * 10-\mathrm{DR}$

Objective function (Weightage for CIRC) $=0.293-$ $0.000140 * \mathrm{x}(1)-0.0087 * \mathrm{x}(2)+0.894 * \mathrm{x}(3)+0.000128 *$ $\mathrm{x}(1) * \mathrm{x}(2)-0.00159 * \mathrm{x}(1) * \mathrm{x}(3)-0.0733 * \mathrm{x}(2) * \mathrm{x}(3)+(10$ $*(0.1913-0.000350 * \mathrm{x}(1)-0.04552 * \mathrm{x}(2)-0.349 * \mathrm{x}(3)+$ $0.000103 * \mathrm{x}(1) * \mathrm{x}(2)+0.000502 * \mathrm{x}(1) * \mathrm{x}(3)+0.0609 *$ $\mathrm{x}(2) * \mathrm{x}(3)))-(0.357-0.000958 * \mathrm{x}(1)-0.1654 * \mathrm{x}(2)+0.603$ $* \mathrm{x}(3)+0.000695 * \mathrm{x}(1) * \mathrm{x}(2)+0.00121 * \mathrm{x}(1) * \mathrm{x}(3)-$ $0.0778 * \mathrm{x}(2) * \mathrm{x}(3))$

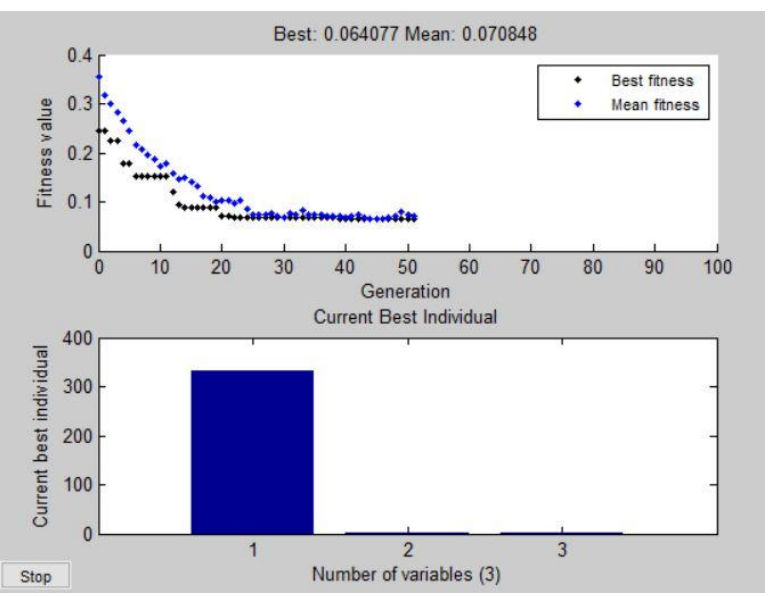

Fig. 5 Weightage for circularity
The equation below depicts the function which has weightage given to the drill rate. Hence the program returns the values which are more preferable for obtaining better drill rate.

$$
\text { Objective }=\text { TOC }+ \text { CIRC }-\mathrm{DR} * 10
$$

Objective function (Weightage for DR $)=0.293-0.000140$ $* \mathrm{x}(1)-0.0087 * \mathrm{x}(2)+0.894 * \mathrm{x}(3)+0.000128 * \mathrm{x}(1) * \mathrm{x}(2)$ $-0.00159 * \mathrm{x}(1) * \mathrm{x}(3)-0.0733 * \mathrm{x}(2) * \mathrm{x}(3)+0.1913-$ $0.000350 * \mathrm{x}(1)-0.04552 * \mathrm{x}(2)-0.349 * \mathrm{x}(3)+0.000103 *$ $\mathrm{x}(1) * \mathrm{x}(2)+0.000502 * \mathrm{x}(1) * \mathrm{x}(3)+0.0609 * \mathrm{x}(2) * \mathrm{x}(3)-$ $(10 *(0.357-0.000958 * \mathrm{x}(1)-0.1654 * \mathrm{x}(2)+0.603 * \mathrm{x}(3)$ $+0.000695 * \mathrm{x}(1) * \mathrm{x}(2)+0.00121 * \mathrm{x}(1) * \mathrm{x}(3)-0.0778 *$ $\mathrm{x}(2) * \mathrm{x}(3)))$;

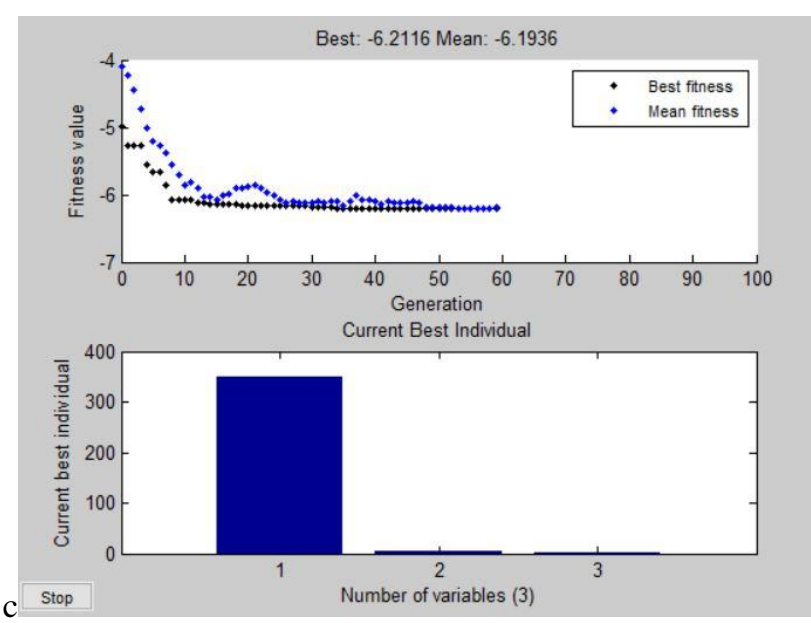

Fig. 6 Weightage for drill rate

Table III Optimized and attainable values

\begin{tabular}{|c|l|l|l|l|l|}
\hline S.No & $\begin{array}{l}\text { Dependent } \\
\text { Parameters }\end{array}$ & $\begin{array}{l}\text { Equal } \\
\text { weightag } \\
\text { e }\end{array}$ & $\begin{array}{l}\text { Weightag } \\
\text { e for } \\
\text { Overcut }\end{array}$ & $\begin{array}{l}\text { Weighta for } \\
\text { ge firculari } \\
\text { ty }\end{array}$ & $\begin{array}{l}\text { Weighta } \\
\text { ge for } \\
\text { Drill } \\
\text { Rate }\end{array}$ \\
\hline 1 & $\begin{array}{l}\text { Water } \\
\text { Pressure }\end{array}$ & $\begin{array}{l}346.535 \\
70\end{array}$ & $\begin{array}{l}331.2085 \\
0\end{array}$ & $\begin{array}{l}331.296 \\
53\end{array}$ & $\begin{array}{l}349.867 \\
48\end{array}$ \\
\hline 2 & $\begin{array}{l}\text { Standoff } \\
\text { Distance }\end{array}$ & 4.49929 & 1.50024 & 1.50164 & 4.49799 \\
\hline 3 & $\begin{array}{l}\text { Abrasive } \\
\text { Flow } \\
\text { Volume }\end{array}$ & 0.43999 & 0.24005 & 0.43992 & 0.43998 \\
\hline \multirow{2}{*}{$\begin{array}{l}\text { Attain } \\
\text { able } \\
\text { Values }\end{array}$} & Overcut & 0.41072 & 0.35897 & 0.41037 & 0.40984 \\
\cline { 2 - 6 } & Circularity & 0.06934 & 0.03633 & 0.01809 & 0.07043 \\
\cline { 2 - 6 } & Drill rate & 0.66024 & 0.34984 & 0.52723 & 0.66918 \\
\hline
\end{tabular}

\section{Conclusion}

A study on abrasive water jet drilling of Inconel 617 was reported. A multiobjective optimization problem was developed using the various parameters and the respective output responses. 
This problem was solved using the Genetic algorithm tool. Different weightages where given to the problem and the change of the results was depicted through the results published. This method has a lot of flexibility and this can be further fine-tuned by fixing appropriate weights for the output responses. This tool can be extremely helpful for the machine operators as they can feed these data and based on the output required by the customer they can change the input factors to obtain the desired results. More responses can be clubbed into the problem and a higher level study can be conducted in future studies.

\section{REFERENCES}

1. Narula, R.. Impacts of steam conditions on plant materials and operations in ultra-supercritical coal power plants; Woodhead Publishing Limited, USA: 2013; 23-56pp doi:10.1533/9780857097514.1.23

2. Zhang, D. Ultra-supercritical coal power plants; Woodhead Publishing: 2013;

3. Liu; Yu, T.; Wang, W. Prediction of the cutting depth of abrasive suspension jet using a BP artificial neural network. IFIP International Federation for Information Processing 2006, 207 , 563-9. doi:10.1007/0-387-34403-9_77

4. Uthayakumar, M.; Khan, M.A.; Kumaran, S.T.; Slota, A. Machinability of Nickel Based Superalloy by Abrasive Water Jet Machining. Materials and Manufacturing Processes 2016, 6914 (January), doi:10.1080/10426914.2015.1103859

5. Escobar-Palafox, G.A.; Gault, R.S.; Ridgway, K. Characterisation of abrasive water-jet process for pocket milling in Inconel 718. Procedia CIRP 2012, 1 (1), 404-8. doi:10.1016/j.procir.2012.04.072

6. Nair, A.; Kumanan, S. Multi performance optimization of abrasive water jet machining of Inconel 617 using WPCA. Materials and Manufacturing Processes 2016, $6914 \quad$ (November), 10426914.2016.1244844. doi:10.1080/10426914.2016.1244844

7. M Junkar; Orbanic, H. An experimental study of drilling small and deep blind holes with an abrasive water jet. Proceedings of 20th International Conference on Industrial Engineering and Engineering Management: Theory and Apply of Industrial Engineering 2013, 218 , 33-40. doi:10.1007/978-3-642-40063-6 4

8. Akkurt, A. The effect of material type and plate thickness on drilling time of abrasive water jet drilling process. Materials and Design 2009, 30 (3), 810-5. doi:10.1016/j.matdes.2008.05.049

9. Palleda, M. A study of taper angles and material removal rates of drilled holes in the abrasive water jet machining process. Journal of Materials Processing Technology 2007, $189 \quad$ (1-3), 292-5. doi:10.1016/j.jmatprotec.2007.01.039

10. Kowsari, K.; Nouraei, H.; James, D.F.; Spelt, J.K.; Papini, M. Abrasive slurry jet micro-machining of holes in brittle and ductile materials. Journal of Materials Processing Tech 2014, 214 (9), 1909-20. doi:10.1016/j.jmatprotec.2014.04.008 